During the past, Vladimir was called phlogiston and everyone and thing had it, especially if you burst into silver flames. Imagine being a tree made into a thousand matchsticks. Once on a ferry going to Larkspur, we stood in the spray watching fog paw through the city. Even now, we love each other.

\title{
If Thou Dislik'st What Thou First Light'st ON
}

I had come to the house, in a cave of trees, I had dreamed of the perfect grey pants, I have a life that did not become, a young sister made of glass. I have been here before, I have done it again.

I like a church, I like a cowl, I like the look of agony.

I love the old melodious lays, I love to listen to you talk to the cat, I love it when they demonstrate the oxygen masks, never messing up their hair.

I met the Bishop on the road, In a coign of the cliff between high and low, In a dark time,

Among wolves and periwinkles, In a station of the metro,

In Breughel's great painting, The Kermess.

Indeed I must confess,

Indigo, magenta, color of ghee, what the hell is the color of ghee?

In June amid the golden fields, what task Hermes assigns we can not tell for here the papyrus rips. In some unused lagoon, some nameless bay, In spite of all the learned say, 
In the depths of the Greyhound Station,

In this world, this isle of dreams,

Intimations of mortality,

In unexpected infancy,

In vain, in vain-the all-composing hours.

Yadda yadda yadda.

I saw the best minds of my generation et cetera,

I saw spiders marching through the air

but let's skip this part, okay?

The usual taste of liquor never brewed, the usual It is June, it is June,

it is ten years since we rowed,

it is 12:20 in New York a Friday

but seems it out of battle I escaped

and I wander lonely as a cloud.

I was angry with a friend,

I went for a walk over the dunes again,

I went into the public 'ouse for a pint o' beer,

I went to the Garden of Love,

but I wonder do you feel today what I do

caught in an index's apparatus as in a thousand

versions of myself but not sure any one exists,

dawns and tangerines, hangovers and phonecalls

made entirely of silence on the other end,

all this fog, a jar in Tennessee, torches

going out? Go down any road far enough

and you'll come to a slaughterhouse

but keep going and you'll reach the sea. 